\title{
FIBRE : a French PC-based regional forest sector model applied to Burgundy
}

\author{
L. Lönnstedt ${ }^{1}$ and J.L. Peyron ${ }^{2}$ \\ 1 Swedish University of Agricultural Sciences, Sweden; \\ 2 Ecole Nationale du Génie Rural, des Eaux et des Forêts, 14, rue Girardet, 54042 Nancy Cedex, \\ France
}

(received 4-12-1987, accepted 5-10-1988)

\begin{abstract}
Summary - Due to an increase in available forest resources, the forest sector can now make a significant contribution towards solving economic and employment problems.

Models can be used in order to assess future trends, both in forest resources and in the wood industry. FIBRE (Filière Bois Régionale model) is an example of this. Its purpose is to illustrate possible consequences for the Burgundy forest sector of different measures for expansion of the sector, under various scenarios. Examples of these measures are modifications in company tax and charge structure and in life-span of equipment. Hypotheses regarding the future are related to development in demand, costs, prices and productivity.

It is obvious from the model runs that expansion of future production capacity for the Burgundy sawmills largely depends on demand development. Another result is that due to the competitive situation, increased market share for the Burgundy sawmills seems unlikely to occur without strong measures being taken. Lastly, the Burgundian nonconiferous forest resources are likely to be harvested at an optimal level in the case of a marked development in national demand for sawnwood, but this is not the case for softwoods. Expansion of the local utilization of softwoods is dependent on the search for new outlets specific to Burgundy, and on the establishment of corresponding new sawmills for a supplementary production capacity of about $100000 \mathrm{~m}^{3}$ over a fifteen year period.
\end{abstract}

model - forest sector - Burgundy - regional policy

Résumé - Un modèle de secteur forestier régional français conçu sur micro-ordinateur et appliqué à la Bourgogne. En raison de l'accroissement de la ressource disponible, le secteur forestier est susceptible de contribuer efficacement à améliorer la situation de l'économie et de l'emploi.

Des modèles peuvent être utilisés pour essayer d'entrevoir les tendances futures, à la fois dans les domaines de la ressource forestière et de l'industrie du bois. FIBRE (modèle de la Filière Bois Régionale) en est un exemple. Il a pour objectif d'illustrer, pour le secteur forestier bourguignon placé dans diverses situations, les conséquences possibles de différentes mesures destinées à provoquer une expansion du secteur. Les mesures peuvent consister à modifier les charges pesant sur les entreprises ou à développer l'équipement industriel. Les hypothèses relatives au futur s'appliquent à l'évolution de la demande, des coûts, des prix et de la productivité du travail. 
Les résultats montrent clairement qu'une expansion de la capacité de production des scieries bourguignonnes dépend en premier lieu du développement de la demande. Par ailleurs, l'accroissement de la part du marché prise par les scieries ne se produira qu'au prix de mesures très fortes, en raison d'une vive concurrence. Enfin, les ressources forestières bourguignonnes feuillues sont susceptibles d'être exploitées à un niveau optimal dans le cas d'un fort développement de la demande nationale de sciages; mais il n'en est pas de même pour les résineux dont la valorisation locale passe par la recherche de nouveaux débouchés spécifiques à la Bourgogne et l'implantation des nouvelles scieries correspondantes à hauteur d'environ $100000 \mathrm{~m}^{3}$ de capacité de productlion supplémentaire en une quinzaine d'années.

modèle - secteur forestier - filière-bois - disponibilités forestières - Bourgogne - politique régionale

\section{Introduction}

French forest resources are increasing rapidly. The net annual increment is presently about 70 million cubic meters over bark $\left(\mathrm{m}^{3} \mathrm{o} . \mathrm{b}\right.$.) and is increased annually by $1-1.5$ million $\mathrm{m}^{3} \mathrm{o} . \mathrm{b}$. The consumption of roundwood is about $40-50$ million $\mathrm{m}^{3}$ o.b. As a consequence, $25-30$ million $\mathrm{m}^{3}$ o.b. are added annually to the inventory of the standing volume.

However, two kinds of problems exist. The first of these concerns forest management problems, resulting from a great diversity of stands, a large number of owners and lack of a real roundwood market. Second, as is true for other French industrial sectors, a number of forest industry plants require modernization, so that the forest industry has difficulty in becoming competitive and in maintaining its share of the market.

The actual consumption of wood in France has decreased during the last few years thanks to recycling activities, but the marketed removals have decreased more than the actual consumption. The difference has been imported. This is remarkable in view of the increase in forest resources; yet France annually imports forest products amounting to about 16 billion francs. Table I describes removals, net import and wood and fiber consumption in 1973 and in 1982.

Table I. Wood requirements in France (in million $\mathrm{m}^{3}$ roundwood equivalent).

\begin{tabular}{lrr}
\hline Variable & 1973 & 1983 \\
\hline Marketed removals & 30.8 & 28.2 \\
Total import minus export & +11.6 & $+\frac{13.4}{41.7}$ \\
Actual consumption of wood & 42.4 & 41.7 \\
Consumption of recycled products & +8.8 & +9.8 \\
\hline Total consumption & 51.2 & 51.5 \\
\hline
\end{tabular}

${ }^{a}$ Consists of raw materials, bulk and final products. Sources : INRA/CERNA.

The French forest policy has mainly been run from Paris; one of its measures was the setting up of National Forest Fund. Administrative regions were, however, created in 1960. In 1972 they were given political power that was increased in 1982. As a result of the economic crisis that has affected many sectors of the economy, the regions are interested in different possibilities for rural development. Forest resources provide the forest industry with the possibility of expansion. The former are of special interest because of the increase in resources that has taken place. 
In this situation, the forest sector requires detailed analysis. Given the increased regional autonomy and the differences that exist both in forests and industry in the various regions, a regional analysis appears judicious. An instrument that could illustrate the competitive situation for the regional forest sectors and the possibilities for increased utilization of the allowable cut for hardwoods and softwoods may provide an efficient means of analysis.

Forest sector models have been developed in several areas of the world, particularly in North America, Scandinavia and in the frame of international organisms such as the International Institute for Applied Systems Analysis (IIASA, Laxemburg, Austria). These models essentially use two main methods: (1) mathematical programming (linear and nonlinear programming); (2) systems dynamics. Mathematical programming has been used in several cases, for instance by Haynes and Adams (1981), Gilless and Buongiorno (1986) or Dykstra and Kallio (1987). Systems dynamics has been used for example, by Kuuluvainen et al. (1981) and Lönnstedt (1986). This second method has been chosen here because it generally allows assessment of simpler models that can easily be run on personal computers.

Thus this paper will present a PC-based simulation model using systems dynamics modelling. Burgundy has been chosen as the experimental region. The possible long-term development of the Burgundy forest sector will be analysed up till around the year 2000 . The historical development from 1975 up till the present day will also be included in the model runs. The analysis will primarily concern demand, sawnwood production, soft and hardwood cuttings and allowable cut.

\section{Model structure}

Four different sections can be distinguished in FIBRE (Filière Bois Régionale); the $P C$-based regional forest sector model :

(1) Policy and scenario section;

(2) Data section;

(3) Calculation section;

(4) Core section.

The core section coordinates the information flow inside the model (Fig. 1).

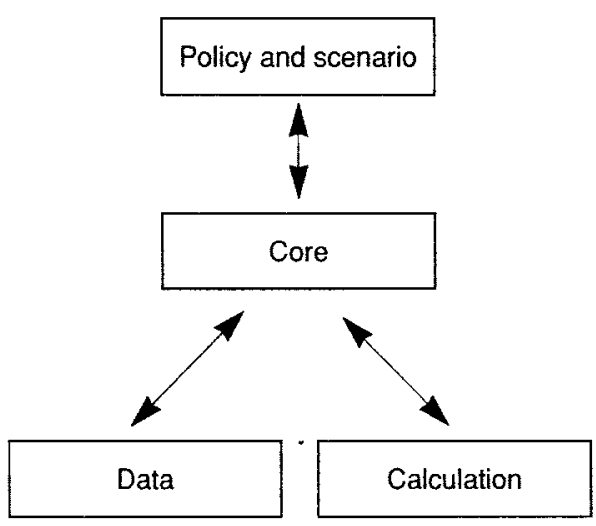

Fig. 1. Outine of the model structure.

\section{Policy and scenario section}

The user works with this section when making interactive runs for examining the consequences of different policies. When using the model the user must specify both chosen measures and assumptions made regarding the development of exogenous variables. For each set of assumptions on future economic development several policies can be run.

\section{Data section}

The data section feeds the model with necessary input data for making calcula- 
tions. The data are organized following the same principle as that for the modules in the calculation section (see below). When running the model for policy analysis the user does not have to include this section. However, when testing the model the user and the model builder usually have to work quite intensively with the data section.

\section{Calculation section}

This section contains the program code, i.e. the equations used. The model builder has the main responsibility for this model section. However, it is important to discuss "decision rules" with the policy maker, and how to translate them into equations. This is one way of getting the user to trust and implement the model.

\section{Summary}

The advantage of structuring the model in this way is that it gives a clear overview of the situation. However, the most important consideration is that the user has to work with just one part of the model when making policy analysis. In the following sections these 3 parts of the model will be presented in more detail, and in the reverse order to that used above.

\section{Calculation modules}

The theoretical base for the model is taken from Lönnstedt (1986). This prototype model describes a national forest sector competing with other forest sectors. The main difference between the prototype model and FIBRE is that this model deals with just one region of France Burgundy. The forest sector of Burgundy is small, and is primarily an important supplier for the local market, and secondarily for the rest of France. The Burgundy forest sector does not affect the Western European market, i.e. consumption or prices. Burgundy is a price taker. In consequence, competing forest sectors have been left out. Consumption and prices are given exogenously. Development of production costs, labour productivity and prime rate are examples of other variables given exogenously and used by the model.

FIBRE consists of 5 calculation modules (Fig. 2) :

(1) Demand and market module;

(2) Industrial module;

(3) Wood market module;

(4) Forest management module;

(5) Forest growth module.

\section{Demand and market module}

The potential for sawnwood in Burgundy is calculated by multiplying the apparent French consumption of sawnwood by the Burgundian market share on the national market.

\section{Industrial module}

This module is made up of 3 sections :

(a) Production capacity section;

(b) Cash flow section;

(c) Revenue and cost section.

The production capacity section keeps track of the capacity volume and its degree of modernity. The cash flow section defines the internal flow of money, and in- and outflow of money from the business. An important aspect is the calculation of how much money is available for new investments. The revenue and cost section calculates gross profit. Investment costs and share of sold residues are exogenously given to the module.

\section{Wood market module}

This module defines the actual cut and the roundwood price for soft and hard wood 
External variables

Other regions

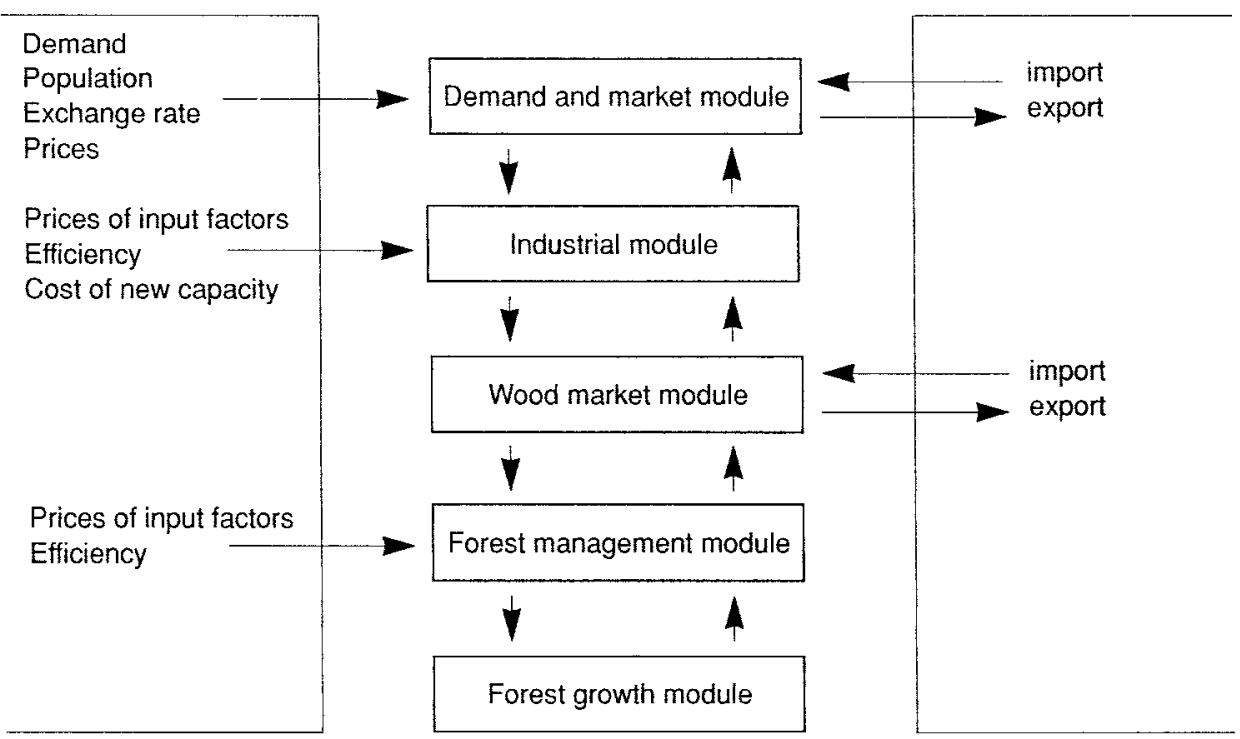

Fig. 2. Linkages between the modules, which essentially consist of price and quantity information

respectively. The actual cut is calculated as the minimum value of potential demand and potential supply. The roundwood price is defined from harvesting cost and stumpage price. The stumpage price depends on (1) the sawmills' ability to pay; (2) the minimum stumpage share that forest owners will accept; and (3) negotiation power for the sawmills and forest owners. The potential demand for pulp- and fuelwood is given exogenously.

\section{Forestry management module}

This module defines the harvesting cost basically from factor costs and labour productivity.

\section{Forest module}

The forest is represented by a diameter class distribution. A distinction is made between softwood and hardwood forests. This part of the model consists of monitor- ing the number of trees in each diameter class, calculating a potential supply from an allowable cut, and distributing the actual cut among the diameter classes according to silvicultural coefficients. The allowable cut is calculated as a share of the biggest stems volume (diameter of $42.5 \mathrm{~cm}$ and more) plus a percentage of the total annual increment (40\%).

\section{Data}

\section{Data requirements}

The data for the model can be grouped into 4 classes according to (a) exogenous variables (scenario variables) given both for the historical and future time period; (b) initial values (1975) of endogenous variables; examples are production capa- 
city and inventory of standing volume; (c) table functions specifying the relationship between 2 variables; (d) constants; examples are planning and building time for industrial equipment and conversion factors. From a more practical point of view, these data can be classified as (1) physical; or (2) economic.

\section{Physical data}

Physical data concern consumption and production of sawmills' products and byproducts, roundwood cuttings, inventory of growing stock and employment.

Demand is estimated from the apparent French consumption of sawnwood. Burgundy sawmills take a share of this national market. The total French demand for sawnwood has been characterised during the last decade by an increasing trend for softwood and a decreasing trend for hardwood. Figure 3 shows that for hardwood neither French nor Burgundian sawmills increased their production in 1979 and 1980 , in spite of increased consumption. One explanation could be the low exchange rate for the dollar during this period. Moreover, Burgundian sawmills lost market shares on the sawn hardwood market over those 10 years.

In the model roundwood cuttings consist of soft and hard sawtimber and other marketed roundwood including veneer logs, pulpwood, miscellaneous industrial wood and fuelwood. Nonmarketed fuelwood is considered as a share of marketed removals. During the last 10 years, the regional and national removals of sawlogs have followed the sawnwood production trends; they have decreased for hardwood and increased somewhat for softwood (Table II). Burgundy exports more sott and hard sawlogs to other regions and countries than it imports. Removals of other marketed roundwood have increased in France, but stayed stable in Burgundy.

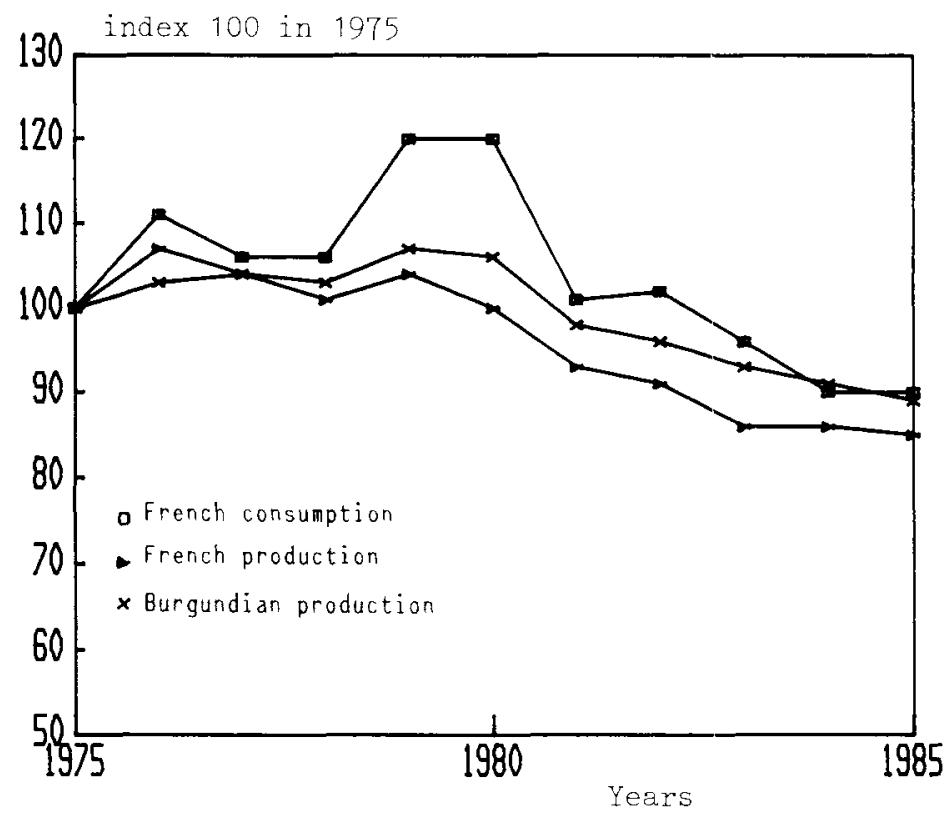

Fig. 3. Consumption and production of sawn hardwood. Source : Ministry of Agriculture. 
Table II. Removals in France and in Burgundy (in thousands $\mathrm{m}^{3}$ o.b. for hardwood and approximately u.b. for softwood).

\begin{tabular}{|c|c|c|c|c|c|c|}
\hline \multirow[t]{3}{*}{ Year } & \multicolumn{3}{|c|}{ Burgundy } & \multicolumn{3}{|c|}{ France } \\
\hline & \multicolumn{2}{|c|}{ Sawiogs } & \multirow[t]{2}{*}{ Other marketed roundwood } & \multicolumn{2}{|c|}{ Sawlogs } & \multirow[t]{2}{*}{ Other marketed roundwood } \\
\hline & hard & soft & & hard & soft & \\
\hline 1975 & 600 & 90 & 706 & 7269 & 8694 & 11862 \\
\hline 1977 & 592 & 112 & 744 & 7327 & 9551 & 11749 \\
\hline 1979 & 588 & 123 & 698 & 7591 & 10113 & 11581 \\
\hline 1981 & 592 & 123 & 731 & 6869 & 9935 & 12025 \\
\hline 1983 & 534 & 108 & 703 & 6871 & 10754 & 12012 \\
\hline 1985 & 531 & 114 & 703 & 7099 & 10426 & 13038 \\
\hline
\end{tabular}

Source : Ministry of Agriculture.

Other important physical data are taken from the forest. They are based on the figures supplied by the National Forest Survey. For each diameter class from class $10(7.5-12.49 \mathrm{~cm})$ to class $60_{+}$ $(57.50 \mathrm{~cm}$ and over) and for both soft and hard trees, the model needs the initial number of standing trees (for 1975, the first year of model runs). The average individual tree volume and diameter increment are given as constants. Functions for mortality and silviculture have to be specified. Lastly, the annual number of trees coming into the first diameter class is necessary. Such a precise description of the forests is required due to the rapid evolution that takes place (Table III).

Employment data for sawmilling and logging activities are considered in an indirect manner according to the following relationship :

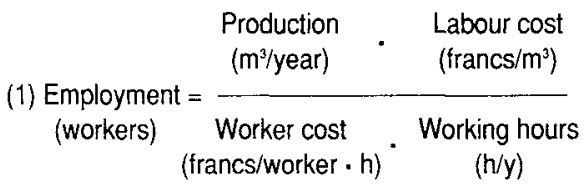

\section{Economic data}

Prices, costs and values are expressed in real terms with 1985 as a base year in order to eliminate inflation fluctuations (during the period from 1975 to 1985 , the annual inflation rate has varied in France between $5-13 \%$ ).

Income for sawmills consists of income from sawnwood and by-products (Fig. 4). It. is distributed into production costs and a gross profit margin. Production costs are composed of wood, labour and other costs including, for example, energy costs. Wood cost is the sum of transportation

Table III. Evolution of forest area, volume and increment 1986 in Burgundy and France.

\begin{tabular}{|c|c|c|c|c|}
\hline \multirow[t]{2}{*}{ Variable } & \multicolumn{3}{|c|}{ Burgundy } & \multirow{2}{*}{$\begin{array}{l}\text { Total in } \\
\text { France }\end{array}$} \\
\hline & hard & soft & total & \\
\hline Forest area (million hectares) & 0.78 & 0.16 & 0.94 & 13.5 \\
\hline Annual growth rate (\%) & -0.5 & 3.1 & 0.1 & 0.3 \\
\hline Growing stock (million $\mathrm{m}^{3}$ ) & 99 & 16 & 117 & 1820 \\
\hline Annual growth rate (\%) & 1.8 & 6.0 & 2.4 & 1.8 \\
\hline Net annual increment (million $\mathrm{m}^{3}$ ) & 3.4 & 1.2 & 4.6 & 70 \\
\hline Annual growth rate (\%) & 1.5 & 9.4 & 3.5 & 2.3 \\
\hline
\end{tabular}

Source: Calculations taken from National Forest Survey data. 
cost, harvesting cost and stumpage price multiplied by the conversion factor. Moreover, the following relationship can be used:

(2) Income $=$ Production $x$ Price

(Francs) $\quad\left(\mathrm{m}^{3}\right) \quad$ (Francs $\left./ \mathrm{m}^{3}\right)$

(3) Sawlog $=$ Sawnwood $x^{\text {Conversion }}$ Consumption $=$ Production $\times$ Factor ( $\mathrm{m}^{3}$ of roundwood) ( $\mathrm{m}^{3}$ of sawnwood) $\left(\mathrm{m}^{3}\right.$ of roundwood/ $\mathrm{m}^{3}$ of sawnwood).

Cash flow data for sawmills are based on the cash flow from operations which consists basically of the gross profit; the latter is obtained from total income by sub- tracting the production costs (Fig. 5). The total cash flow is the sum of the cash flow from operations and the external cash inflow. It is used for taxes, interests, dividends, repayments and investments in new industrial capacity. The rest is allocated to financial resources (Fig. 5).

\section{Difficulties related to data}

Two main problems must be solved when looking for and using data : (1) availability; and (2) consistency.
Resources

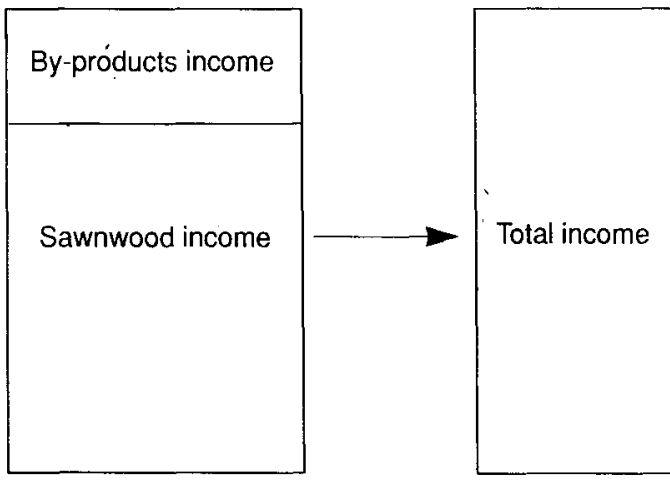

Uses

\begin{tabular}{|l|l|}
\hline & Gross profit margin \\
\hline & Other costs \\
\hline Wood costs & Labour costs \\
\hline & Harvesting \\
\hline & Stumpage price \\
\hline
\end{tabular}

Fig. 4. Income and cost structure.

Resources

\begin{tabular}{|c|c|c|}
\hline $\begin{array}{c}\text { Cash flow } \\
\text { from operations }\end{array}$ & Total cash flow \\
\hline External cash inflow
\end{tabular}

Fig. 5. Cash flow. 


\section{Availability}

It is often more difficult to collect data at a regional level than at a national one. However, in France, an exception is that forest data is more easily available for a region than for the whole of France. In some cases, one cannot find or estimate the required data. One has then to adapt the structure of the model to this. For example, the lack of inter-regional trade data has been solved for sawnwood by calculating the share that the Burgundian sawmill industry takes of the total national sawnwood market.

\section{Consistency}

Special attention should be paid to the consistency between data. Roundwood volume is one example. Several roundwood volumes can be considered according to whether branches, bark and nonmarketed fuelwood are taken into account or not.

\section{Summary}

Data are certainly a major constraint when building a model, but the latter can be very

Table IV. Example of policies and indication of the corresponding decision maker.

\begin{tabular}{ll}
\hline Policy & Decision maker \\
\hline Taxes and charges & Politicians \\
Tariffs and duties & Politicians \\
Subsidies & Politicians \\
Prime rate & Politicians \\
Investments & Managers \\
Life-span & Managers \\
\hline
\end{tabular}

useful for specifying in which fields the empirical data on the forest sector ought to be improved. It is one of the interests of such an approach.

\section{Policies and scenarios}

Examples of policies that could be tested in the laboratory formed by the model are changes in (a) taxes and charges; (b) tariffs and duties; (c) subsidies; (d) prime rate; (e) investments; and ( $f$ ) life-span of equipment (Table IV). The decision regarding the 4 first-mentioned policies was in the hands of politicians, while the decision about the last 2 is made by managers. For managers, the model runs describe a possible future development for the forest sector. This development could be taken as input for more detailed company models.

Taking into consideration the rural French situation with its economic problems, unemployment and growing forest resources, it is likely that a forest policy program will primarily try to stimulate managers to increase their investments through improving economic conditions. The program could, for example, consist of favourable deduction rules and loans and perhaps also a decrease in taxes. The international economic situation and the structure of the European Economic Community indicate that it is difficult for politicians to use means such as tariffs and subsidies.

Scenarios on future economic development have to be specified by making

Table V. An example of definitions for different scenarios.

\begin{tabular}{lllll}
\hline Scenario & Demand & Prices & Costs & Productivity \\
\hline (1) Base & Expert forecast and balanced evolution of prices and costs \\
(2) Growth & High & High & Low & High \\
(3) Stagnation & Stagnation & Low & High & Low \\
\hline
\end{tabular}


Table VI. Model runs presentation.

\begin{tabular}{llll}
\hline & $\begin{array}{c}\text { Base scenario } \\
\text { (1) }\end{array}$ & \multicolumn{1}{c}{$\begin{array}{c}\text { Growth scenario } \\
\text { (2) }\end{array}$} & $\begin{array}{l}\text { Stagnation scenario } \\
\text { (3) }\end{array}$ \\
\hline (a) Usual policy & $\begin{array}{l}\text { Run } 1 a \\
\text { Reference run }\end{array}$ & $\begin{array}{l}\text { Run } 2 b \\
\text { Strong development run }\end{array}$ & $\begin{array}{l}\text { Run 3a } \\
\text { Weak development run }\end{array}$ \\
(b) Special policy & $\begin{array}{l}\text { Run } 1 b \\
\text { Reference run } \\
\text { with growth policy }\end{array}$ & $\begin{array}{l}\text { Run } 3 b \\
\text { Weak development } \\
\text { with growth policy }\end{array}$ \\
\hline
\end{tabular}

assumptions about (a) demand; (b) price and exchange rate; (c) cost of production factors such as labour and energy; and (d) labour productivity or efficiency in using production factors. Several scenarios are usually simulated and compared. In a first approach, 3 scenarios are considered (Table V) : (1) a base scenario corresponding to expert forecasts of demand and to a balanced evolution in prices and costs; (2) a growth scenario characterized by high increase in consumption, favourable prices or high dollar value, low costs increase relative to competitors and a good productivity development; (3) a stagnation scenario that presents the opposite picture.

Policies and scenarios are combined in model runs according to purpose. In the case of FIBRE, the main questions are : (1) Will the forest industries succeed in increasing their utilization of the growing forest resources in the future ? (2) What will the effects be of different policies to increase the industrial utilization of these forest resources? Five runs will thus be studied (Table VI) and their results presented in the next section.

\section{Model runs}

\section{Run 1a: Reference run}

In the Reference run, it is assumed that the French consumption of sawn hard- wood in the future, on an average, will increase by $2 \%$ per year from a level of 3.4 million $\mathrm{m}^{3}$ in 1985 (Table VII). Consumption of sawn softwood is expected to increase by $1.5 \%$ per year from a level of 6.9 million $\mathrm{m}^{3}$ in 1985 . The theoretical Burgundy consumption represented by the French consumption times the Burgundy population share - is assumed to increase at a lower level as weak population development is expected. In 1985 the consumption level of sawn hardwood was $\approx 100000 \mathrm{~m}^{3}$ and $\approx 200000 \mathrm{~m}^{3}$ for sawn softwood.

As for marketed roundwood other than sawlogs, the Burgundy consumption plus net export is expected to decrease by $2.5 \%$ per year for hardwood and to increase by $2.5 \%$ for softwood. In 1985 the consumption level of marketed roundwood other than sawlogs for hardwood and softwood is estimated to $400 \quad 000$ and $145000 \mathrm{~m}^{3}$ o.b., respectively.

In the model the price of sawn hard and softwood in 1985 is $\approx 1550$ and 900 Francs $/ \mathrm{m}^{3}$, respectively (Table VII). The real price is, on average, assumed to decrease by $0.60 \%$ and $0.75 \%$ per annum, respectively. Behind this price development is, among other things, an assumed increase in labour productivity at an average of $4 \%$ per year. Cost of labour including social costs, that in 1985 was $\approx 60 \mathrm{Francs} / \mathrm{h}$, is expected to increase in real terms at an average of $2.3 \%$ per year (Table VI). The cost development for other 
Table VII. Historical and assumed future development in Reference run (Run 1a) for some key scenario variables.

\begin{tabular}{|c|c|c|c|c|c|c|c|c|c|}
\hline \multirow[t]{2}{*}{ Variable } & \multicolumn{7}{|l|}{ Year } & \multicolumn{2}{|c|}{$\begin{array}{c}\text { Average change } \\
(\% / y r)\end{array}$} \\
\hline & 1975 & 1980 & 1985 & 1990 & 1995 & 2000 & 2005 & $1975-1985$ & $1985-2005$ \\
\hline \multicolumn{10}{|c|}{ Consumption sawn hardwood $\left(1000 \mathrm{~m}^{3}\right)$} \\
\hline France & 3500 & 4200 & 3400 & 3800 & 4100 & 4600 & 5100 & -0.3 & 2.0 \\
\hline Burgundy & 100 & 125 & 100 & 110 & 120 & 130 & 140 & -0.5 & 1.6 \\
\hline \multicolumn{10}{|c|}{ Consumption sawn softwood $\left(1000 \mathrm{~m}^{3}\right)$} \\
\hline France & 6100 & 8100 & 6900 & 7400 & 8000 & 8600 & 9200 & 1.2 & 1.5 \\
\hline Burgundy & 180 & 240 & 200 & 210 & 230 & 240 & 250 & 0.8 & 1.2 \\
\hline \multicolumn{10}{|c|}{ Consumption of pulpwood, fuelwood, etc. in Burgundy ( $1000 \mathrm{~m}^{3} \mathrm{~s}$ o.b.) } \\
\hline Hard & 600 & 700 & 500 & 400 & 350 & 350 & 300 & -1.8 & -2.5 \\
\hline Soft & 100 & 100 & 150 & 150 & 200 & 200 & 250 & 4.1 & 2.5 \\
\hline \multicolumn{10}{|c|}{ Price of sawnwood (francs $\left./ \mathrm{m}^{3}\right)$} \\
\hline Hard & 1850 & 2050 & 1550 & 1500 & 1450 & 1400 & 1350 & -1.8 & -0.6 \\
\hline Soft & 1150 & 1200 & 900 & 850 & 800 & 800 & 750 & -2.8 & -0.75 \\
\hline \multicolumn{10}{|c|}{ Cost of labour (francs/h) } \\
\hline & 40 & 50 & 60 & 65 & 75 & 80 & 90 & 3.4 & 2.3 \\
\hline
\end{tabular}

production costs is assumed to be somewhat less $(2.0 \%)$.

In the Reference run, the future production development of sawn hardwood in Burgundy more or less follows the increase in consumption, i.e. the market share remains quite stable (Fig. 6). The production capacity, which was $\approx 305000 \mathrm{~m}^{3}$ in 1985 , should increase to $\approx 410000 \mathrm{~m}^{3}$ by 2005. The main explanation for this unchanged market share development is the assumption regarding the same development of production costs in Burgundy as in competing regions. As a consequence, the gross profit margin also remains quite stable. However, even if production increases, the actual cut remains practically stable (pulpwood demand, is assumed to decrease), while the allowable cut increases by $\approx 0.9 \%$ per year. Thus, the sawmills succeed in utilizing just a part of the growing forest resources in this run. The opportunities for an increased export of roundwood to forest industries in other regions are good.

In the Reference run the picture is more or less the same for the Burgundy produc- tion of sawn softwood (Fig. 7). Production increases with consumption growth. The market share remains more or less stable. The gross profit margin is also quite stable. The allowable cut increases by as much as $3.6 \%$ per year on average while the actual cut only increases by $2.0 \%$.

Run $1 b$ : Reference run with growth policy

The main conclusion from the previous run was that even if the Burgundy sawmills increased their production, the allowable cut would increase more than the actual cut. Thus it is possible to further increase the utilization of the growing forest resources. With a given consumption development, the question is how to get the industries to increase their market share ? One possibility would be to adopt a more active market approach. Another would be to become more competitive. In this run we will look at the possible consequences if this last policy is followed.

The structure of the Burgundy sawmills could be much improved. Many of the 


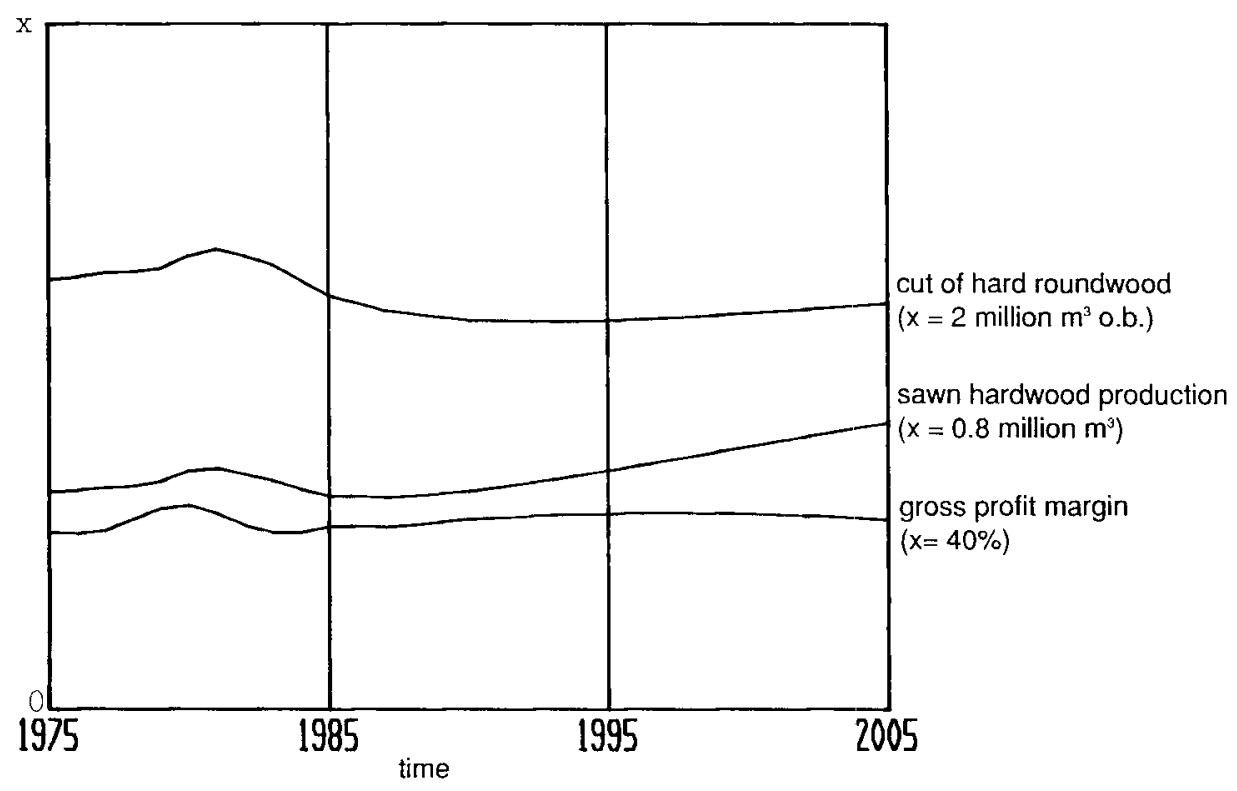

Fig. 6. Reference run for sawn hardwood. Moving average values for the last 4 years.

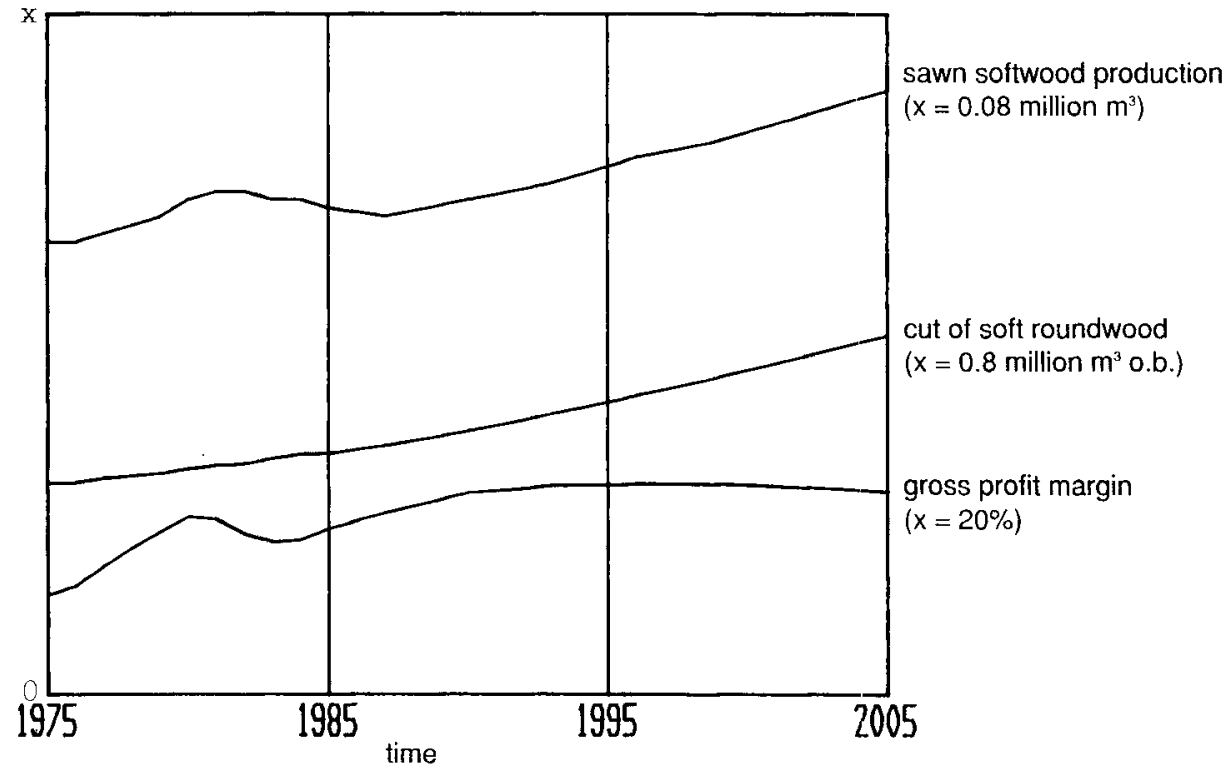

Fig. 7. Reference run for sawn softwood. Moving average values for the last 4 years. 
mills are old, and methods are old-fashioned. Some are too small to be able to compete outside a very local market. In this run, it is assumed that as of 1990 a substantial modernization of the Burgundy sawmills will take place. In order to stimulate investments in new mills and equipment it is assumed that the national and local policy-makers will successfully control, and when compared with other countries, somewhat reduce cost-development. The prime rate is also somewhat reduced in addition to taxes and charges. Furthermore, it is assumed that the sawmill owners will keep more of the profit in the enterprise for investment purposes. In total, the cash outflow will be reduced by $30 \%$ as of 1990 .

As expected, the result is an increased market share and expansion of production. However, it is difficult and it takes times to increase the market share ${ }^{\text {. One }}$ has to take production from someone else and competition will be increased. Compared with total French consumption, the market share for sawn hardwood in 2005 will increase somewhat, but will still be

" It should be noted that it is very difficult to obtain good data on how the market share will develop under different competitive situations. The given figures should therefore be viewed as examples. $\approx 7 \%$. This means a production of $370000 \mathrm{~m}^{3}$ instead of 335000 . The market share for sawn softwood also increases somewhat, but will still be $<1 \%$. This means that the production increases from 70000 to $75000 \mathrm{~m}^{3}$. From the point of view of forest resources there is still plenty of room for industrial expansion, notably in the softwood case. Perhaps the main effect of these policies can be seen at the gross profit margin. At the turn of the century it will have increased by $\approx 25 \%$

\section{Run 2 : Strong development run}

In this run, some of the scenario variables are changed while the policy is the same as in the Reference run (Table VIII). It is assumed that future market growth will be stronger. Consumption of sawn hard and softwood is expected to increase by 3.1 (2.0) and $2.0(1.5) \%$ respectively. Demand for marketed roundwood other than sawlogs will increase for soft pulpwood by $4.0 \%$ (2.5) per year while it will be the same $(-2.5 \%)$ for hard pulpwood. Labour productivity is expected to increase by $5.0 \%(4.0)$ per year on average.

In the model run, the production of sawnwood more or less follows the expansion of the market. The Burgundy production of sawn hard and softwood in the

Table VIII. Assumption about average annual change rate 1985-2005 for some scenario variables.

\begin{tabular}{llllll}
\hline $\begin{array}{l}\text { Scenario } \\
\text { variables }\end{array}$ & $\begin{array}{l}\text { Run 1a } \\
\text { Reference } \\
\text { run }\end{array}$ & $\begin{array}{l}\text { Run 1b } \\
\text { Reference } \\
\text { run with } \\
\text { growth policy }\end{array}$ & $\begin{array}{l}\text { Run 2 } \\
\text { Strong } \\
\text { development } \\
\text { run }\end{array}$ & $\begin{array}{l}\text { Run 3a } \\
\text { Weak } \\
\text { development } \\
\text { run }\end{array}$ & $\begin{array}{l}\text { Run 3b } \\
\text { Weak development } \\
\text { run with } \\
\text { growth policy }\end{array}$ \\
\hline $\begin{array}{l}\text { Demand for sawnwood } \\
\text { Hard }\end{array}$ & 2.0 & 2.0 & 3.1 & 0.5 & 0.5 \\
$\quad$ Soft & 1.5 & 1.5 & 2.0 & 0.5 & 0.5 \\
$\begin{array}{l}\text { Demand for roundwood other than sawnlogs } \\
\text { Hard }\end{array} \quad-2.5$ & -2.5 & 0.0 & -2.5 & -2.5 \\
$\quad$ Soft & 2.5 & 2.5 & 4.0 & 1.5 & 1.5 \\
Labour cost & 4.0 & 4.0 & 5.0 & 3.0 & 3.0 \\
Labour productivity & 4.0 & 4.0 & 5.0 & 3.0 & 3.0 \\
\hline
\end{tabular}




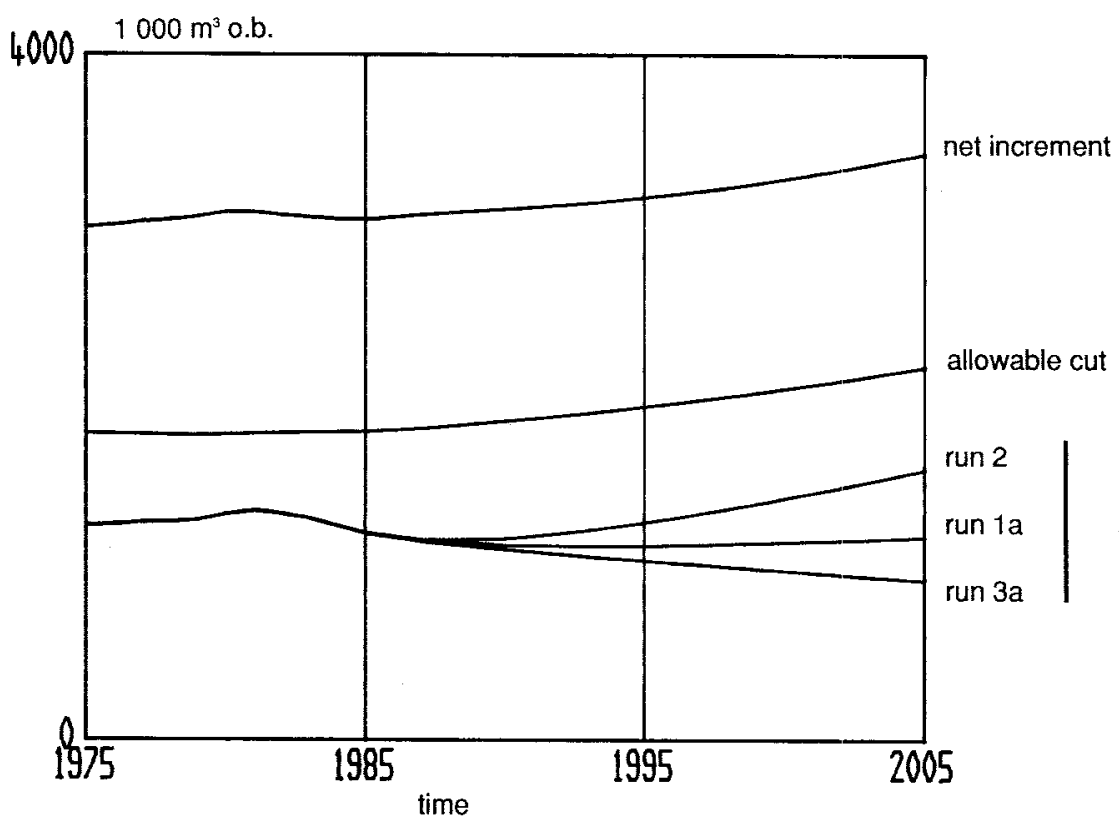

actual cut

Fig. 8. Actual cut compared with the allowable cut and the net increment for hardwood forests and several scenarios. Moving average values for the last 4 years.

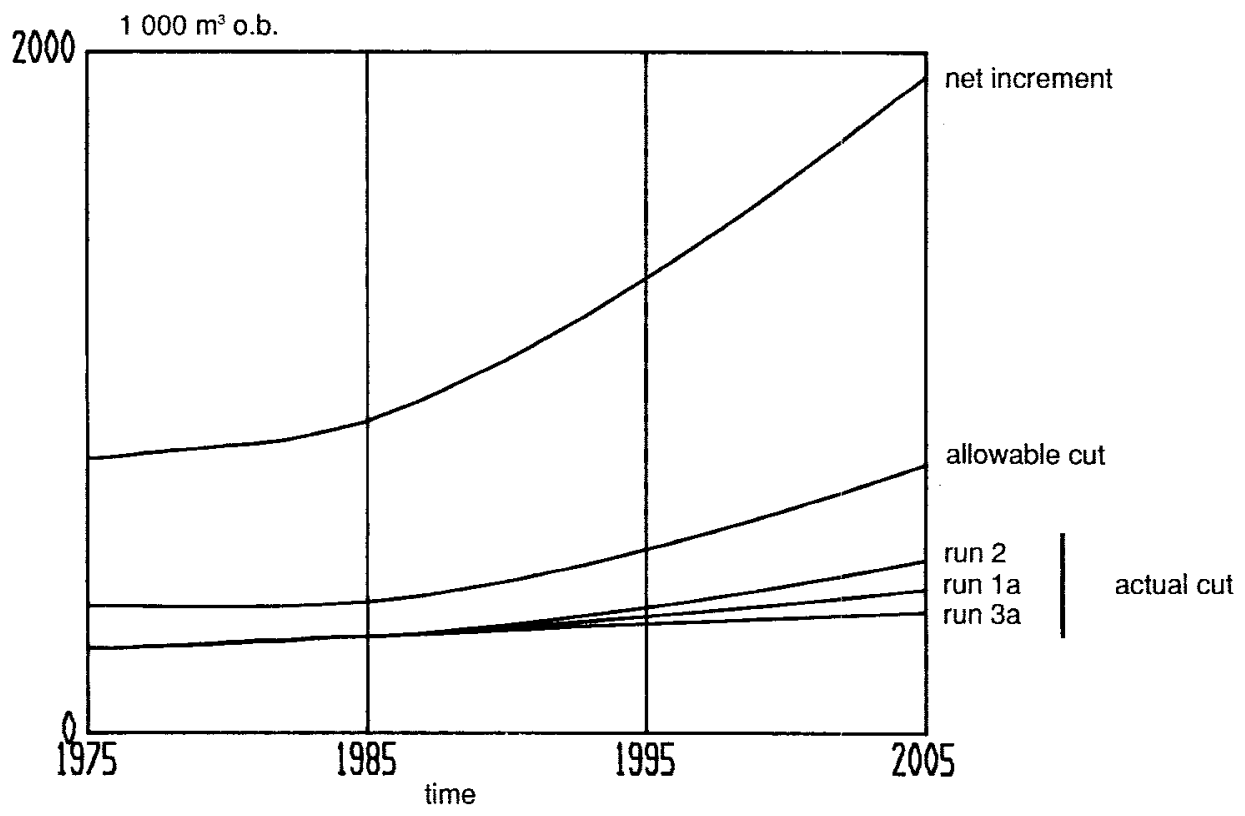

Fig. 9. Actual cut compared with the allowable cut and the net increment for softwood forests and several scenarios. Moving average values for the last 4 years. 


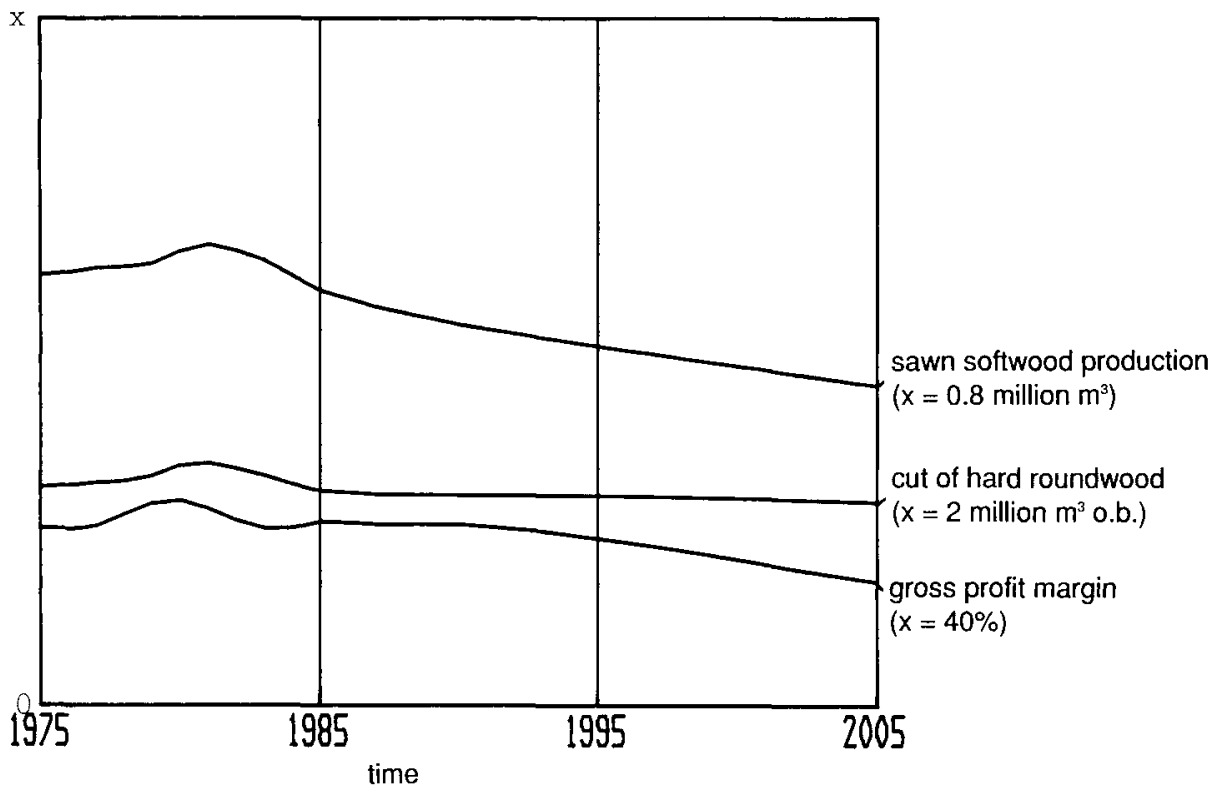

Fig. 10. Weak economic development run for sawn hardwood. Moving average values for the last 4 years.

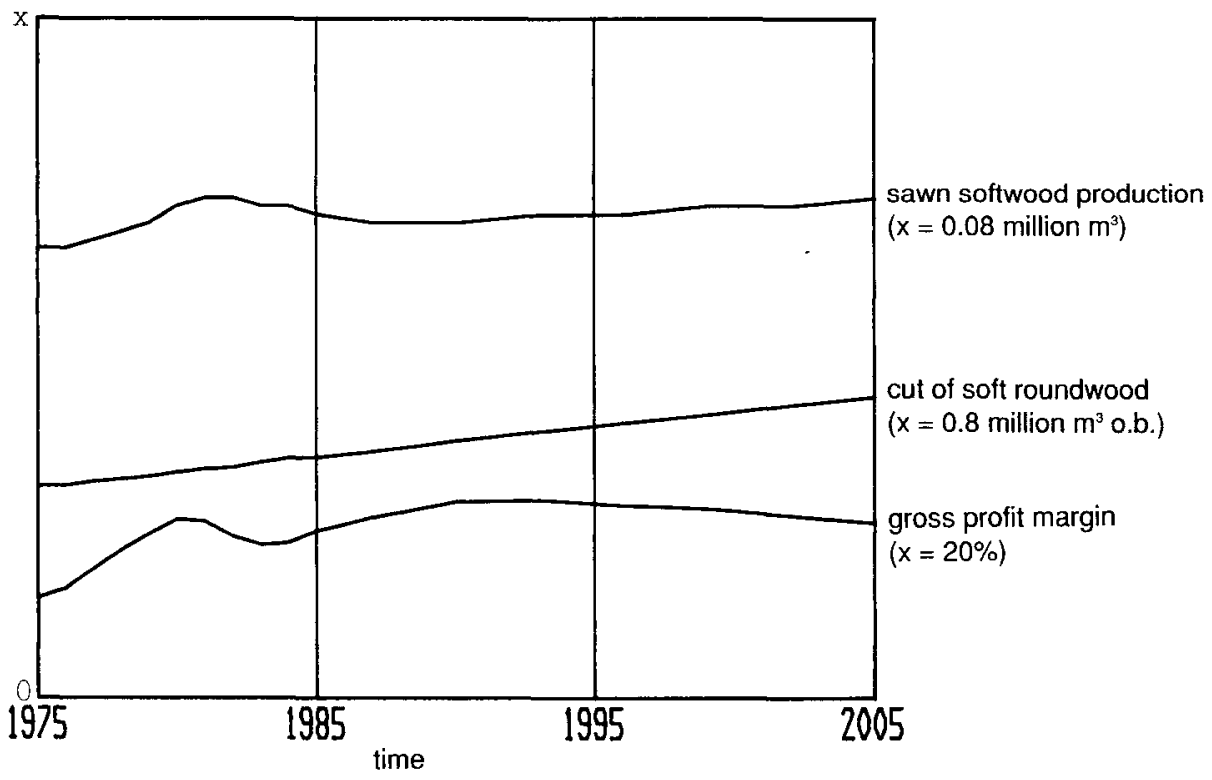

Fig. 11. Weak economic development run for sawn softwood. Moving average values for the last 4 years. 
model run for 2005 is $\approx 430000$ and $80000 \mathrm{~m}^{3}$ respectively. The market share will have increased somewhat compared with the situation in 1985. The explanation is that the quick expansion of the production capacity allows modernisation of the industrial structure, which has a positive effect on production costs and also competitiveness. This can also be seen in the development of the gross profit margin.

The softwood allowable cut goes on increasing more rapidly than the actual cut, in spite of the increase in consumption and industrial production (Fig. 9). The development for hardwood is different; the hardwood cut level begins to make up for the allowable cut. The actual cut increases by $1.4 \%$ per year (instead of $0 \%$ in the reference run) and the allowable cut by $0.9 \%$ after 1985 (Fig. 8).

\section{Run 3a : Weak development}

This run is opposite to the previous one. The future market development is assumed to be weak (Table VIII). Demand for sawn hard and softwood increases by just $0.5 \%$ per year on average with 2.0 and $1.5 \%$, respectively, in the reference run. Demand for marketed roundwood other than sawlogs increases by just $1.5 \%$ (2.5) per year while it ren iains the same as in the reference run $(-2.5 \%)$ for pulp hardwood. Labour productivity is assumed to increase by $3.0 \%$ (4.0) per year and labour cost by $3.0 \%$ (2.3) per year.

This pessimistic future scenario has quite a negative impact on the Burgundy sawmills (Figs. 10 and 11). The production volume will be stable both for sawn hardwood and softwood. The industrial structure will remain old-fashioned and in consequence the competitiveness will decrease. The Burgundy sawmills will slowly lose market shares. The gross profit margin will tend to decrease. The growing forest resources will remain unutilized.
Run $3 b$ : Weak development with growth policy

If future development is as described in the previous scenario, it would probably be very important for Burgundy, as well as for other regions, to utilize all possible regional resources. Utilization of the growing forest resources is one possibility. In order to achieve this, the same policies as in Run $1 b$ must be applied. Thus an attempt is made to increase investments in new sawmills and new equipment, in order to obtain a modern industrial structure. This strategy should result in a favourable development of the production costs, which hopefully will mean increased market shares and increased production.

In the model run this policy helps, but perhaps not as much as expected. It is true that production increases somewhat, but it is far from the level of that in the Reference run. However, one effect of this policy is that the gross profit margin remains more or less at the same level as in the reference run.

Supplementary runs in the softwood case $(1 c, 2 c, 3 c)$

The previous runs have shown that for softwood even a strong development scenario is not strong enough to lead to complete utilization of the resources. The reason is the present very low number of mills sawing softwood in Burgundy. Consequently the regular development simulated by the model must be strengthened by a more dramatic evolution. Thus 3 other runs $(1 c, 2 c$ and $3 c$ ) have been simulated for softwood under 3 assumptions : (1) 2 new mills, each of them producing $50,000 \mathrm{~m}^{3}$ of sawnwood, will be established externally in Burgundy for 1990 and 2000 respectively; (2) the corresponding new markets are hypothesized as existing; and (3) the same policies as is runs $1 b, 2$ and $3 \mathrm{~b}$ have been respectively applied. 
Table IX. Index for (1) production capacity and (2) cutting intensity in Burgundy.

\begin{tabular}{|c|c|c|c|c|}
\hline \multirow[t]{2}{*}{ Model runs } & \multicolumn{2}{|c|}{$\begin{array}{l}\text { (1) Production capacity } \\
\text { in } 2005(1985=100)\end{array}$} & \multicolumn{2}{|c|}{$\begin{array}{l}\text { (2) Cutting intensity } \\
\text { in } 2005(1985=100)\end{array}$} \\
\hline & Sawn hardwood & Sawn softwood & Sawn hardwood & Sawn softwood \\
\hline \multirow{3}{*}{$\begin{array}{l}\text { 1a Reference run } \\
\mathrm{b} \text { id. with growth policy } \\
\mathrm{c} \text { id. with new markets } \\
\text { and capacities }\end{array}$} & 135 & 125 & 81 & 73 \\
\hline & 150 & 130 & 88 & 74 \\
\hline & - & 249 & - & 10 \\
\hline \multirow{2}{*}{$\begin{array}{l}2 \text { Strong development run } \\
\mathrm{c} \text { id. with new markets } \\
\text { and capacities }\end{array}$} & 170 & 140 & 109 & 89 \\
\hline & - & 267 & - & 117 \\
\hline \multirow{3}{*}{$\begin{array}{l}\text { 3a Weak development run } \\
\text { b id. with growth policy } \\
\mathrm{c} \text { id. with newmarkets } \\
\text { and capacities }\end{array}$} & 95 & 105 & 64 & 61 \\
\hline & 105 & 110 & 68 & 62 \\
\hline & - & 221 & - & 91 \\
\hline
\end{tabular}

These changes have obviously favourable consequences on the Burgundian softwood sector. The sawn softwood production increases by $4.9 \%$ (run 1c), $5.1 \%$ (run 2c) or $4.4 \%$ (run $3 c$ ) per year and in 2005 reaches the level of $143,000 \mathrm{~m}^{3}$ (run 1c), $154,000 \mathrm{~m}^{3}$ (run 2c) and $134,000 \mathrm{~m}^{3}$ (run 3c) from an initial level of $57,000 \mathrm{~m}^{3}$ in 1985. In these new runs, the gross profit margin of remaining mills is improved by $\approx 0.2 \%$ in 2005 . From a forest point of view, the actual cut begins to make up for the allowable cut, except in the stagnation case (run 3c). Between $1985-2005$, the allowable cut increases by $3.6 \%$ per year whilst during the same period, the increase in the actual cut is $3.8 \%$ per year in run $1 \mathrm{c}, 4.4 \%$ in run $2 \mathrm{c}$ and $3.1 \%$ for run $3 \mathrm{c}$.

\section{Conclusion}

At the end of the section on Policies and scenarios, a first question was raised; whether in the future the forest industry could succeed in utilizing the growing forest resources. In order to have a better base, and perhaps, even more important- ly, a better understanding of the way the system behaves, the laboratory that FIBRE supplies has been used. From the model runs (Table IX) it is obvious that some of them allow a satisfactory utilization of forest resources, especially when the cutting intensity (actual related to allowable cut) index is $\geq 100$; it can actually be greater than 100 if the cut has previously been too small.

The second question raised in the Policy and scenarios section was how to stimulate the utilization of forest resources. The hardwood and softwood cases must be distinguished in this answer. The utilization of the hardwood resources depends mainly on market development, but a growth policy can also improve both the situation of mills and the utilization of forest resources (Table $I X$ ). This policy consists mainly of substantial modernization of the Burgundian sawmills, a reduction in cost development and a drop in cash outflow. As for the sottwood resources, market development seems to be the only way to increase regional wood consumption. The effect of a growth policy is limited to an improvement in the profit level of sawmills. But a regular develop- 
ment of the regional market, similar to the French one, is not strong enough because of the low initial production relative to the Burgundian coniferous area. In this case, the solution consists in finding new outlets, specific to Burgundy, and in building new mills. In a balanced situation such as the reference one, a good solution seems to be found with the establishment of new capacities of $50,000 \mathrm{~m}^{3}$ in 1990 and $50,000 \mathrm{~m}^{3}$ in 2000 , provided that the corresponding outlets exist.

Finally, new market shares must be found and investments in new sawmills and equipment will then have to increase. This evolution can be regular for hardwood and requires improvements in product marketing, in supplies of raw materials, and in research and development activity. It should be more rapid and more efficient in the case of softwood, otherwise exports to other regions will become larger and larger. However, this last possibility can be a temporary solution for increasing economic wealth, creating labour opportunities and preserving the forest's future.

The presented runs should be viewed as examples. It is up to the decisionmaker to specify which scenarios and policies he is interested in. FIBRE is easily accessible as it is PC-based. The user works with a set of menus that make it easy to change assumptions, and to check the result of a run only takes a few minutes.

\section{Acknowledgement}

The research for this paper was supported jointly by the Forestry section and the Research section of the French Government. Only the authors' opinions are expressed in this paper.

\section{References}

Badre M. (1984) Forêt et Marché du Bois. Hatier, pp. 80

Dykstra D.P. \& Kallio M. (1987) Introduction to the IIASA Forest Sector Model. In : The Global Forest Sector : An Analytical Perspective (Kallio M., Dykstra D.P. \& Birkley C.S eds.), John Wiley and Sons, Chichester, pp. 459-472

Gilless J.K. \& Buongiorno J. (1986) Papyrus : A model of the North American pulp and paper industry. For. Sci. Monogr. 28

Guillon P. (1978) La Filière - Bois Française en 1973. INRA, Nancy, pp. 93 + annexes.

Haynes R.W. \& Adams D.M. (1983) Research on TAMM and other elements of the US Timber Assessment. In : Forest Sector Models (1981) (Seppala R., Row C. \& Morgan A., eds) AB Academic Publishers, Berkhamsted, England, pp. 9-25

Kuuluvainen J., Seppala H. \& Seppala R. (1977) A planning model for the Finnish Forest Sector. Nordic Forest Economics Seminar, Varparanta, pp. 9

Lönnstedt L. (1986) A Dynamic Forest Sector Model with a Swedish Case. For. Sci. 32 (2), 377-397

Naurois M. de (1985) La filière - bois en 1973 et 1982. CERNA, Ecole Nationale Supérieure des Mines, Paris;

Peyron J.L. (1986) Elaboration d'un Schéma de Modèle de Secteur Forestier Régional. Application à la Région Bourgogne. ENGREF, Nancy, pp. $94+$ annexes 